\title{
Health Policy Analysis: Antitrust Law and Regulation on Health Care Providers
}

\author{
Henry O’Lawrence ${ }^{1 *}$, Lisa Saunders ${ }^{2}$, Mei Li ${ }^{2}$, Martha Kelly ${ }^{2}$ \\ ${ }^{1}$ CSULB, Long Beach, UNITED STATES \\ 2 Samford University, Alabama, UNITED STATES
}

*Corresponding Author: henry.olawrence@csulb.edu

Citation: O'Lawrence, H., Saunders, L., Li, M. and Kelly, M. (2018). Health Policy Analysis: Antitrust Law and Regulation on Health Care Providers. European Journal of Environment and Public Health, 2(1), 02. https://doi.org/10.20897/ejeph/82620

Published: February 28, 2018

\begin{abstract}
The purpose of this theoretical policy analysis report was to determine if antitrust laws should be based upon concrete wrongful conduct and should not force the health care industry to adopt defensive, cumbersome business practices that actually impede their ability to compete. The role of antitrust is to ensure that competition is preserved and protected so that it can be harnessed. It is in the government interest to supports efforts that bring more competition to the health insurance marketplace that lowers costs, expand choice, improve quality; with the role of antitrust to ensure that competition is preserved and protected to help improving the U.S. health care system, together with regulation to expand coverage and control cost of health care for general population. Therefore, antitrust cases and sanctions need to be tightly tied to defensible theories of wrongful conduct in order to properly reflect what society thinks is wrong and clarify what is punishable conduct.
\end{abstract}

Keywords: antitrust law, regulations, policy

\section{INTRODUCTION}

Antitrust regulations are known to influence hospitals in their transition from a managed care system to a consume-driven health care system. Antitrust rules and regulations can be difficult to understand and comply with, as the law only sanctions certain kinds of anticompetitive behavior and can be fairly nuanced as far as who is protected and who has the option to sue when wronged by monopolies and conspiracies in restraint of trade. According to Bork (2009), the increasingly complex U.S. antitrust laws are commonly referred to as competition laws and competition in the health care industry is the process by which the provider in the marketplace strives to gain something by establishing superiority over other providers who are trying to do the same. When the government pays for more than $36 \%$ of the health care provided and with the remaining care regulated by government, it is clear why the concept of free enterprise is totally theoretical in today's marketplace; and free enterprise in health care only exists in theory and does not exist in reality (CMS, 2015).

In September 1993, the Department of Justice and the Federal Trade Commission (the "Agencies") issued six statements of antitrust enforcement policies regarding mergers and various joint activities in the health care area. The six policy statements addressed: (1) hospital mergers; (2) hospital joint ventures involving high-technology or other expensive medical equipment; (3) physicians' provision of information to purchasers of health care services; (4) hospital participation in exchanges of price and cost information; (5) health care providers' joint purchasing arrangements; and (6) physician network joint ventures. Antitrust laws are typically known to balance potential pro-competitive benefits against potential anticompetitive effects and it does not penalize health care providers 
who dominate their markets on their own merit. It only penalize those that intentionally dominate the market through wrongful conduct (Areeda and Hovenkamp, 2015; Bork, 2009).

Overall, antitrust law protect the consumer by ensuring there is a market driven by competition and that the consumer has a choice for health care and can apply it to most healthcare organizations. There are both federal and state antitrust laws. There are four main antitrust federal laws which are: (a) the Sherman Antitrust Act, (b) the Clayton Act, (c) the Federal Trade Commission Act, and (d) the Robinson-Patman Act (which is the amendment to Clayton Act). The Sherman Act of 1890 focuses on eliminating monopolies which are healthcare organizations that control a market so that consumer has no choice in health care; and targets price fixing among competitors. The Clayton Act of 1914 was passed to supplement the Sherman Act, as amended by the RobinsonPatman Act, which issues further restrictions on mergers and acquisitions (Niles, 2018).

The Act focused more on hospitals and there are no criminal penalties for violations of the Act unlike the Sherman Act. The Act also allows individuals to sue for three times their actual damages, plus legal costs. The Hart-Scott-Rodino Antitrust Improvement Act of 1976 is an amendment to the Clayton Act to ensure that those hospitals and other entities that entered mergers, acquisitions, and joint ventures must notify the DOJ and the FTC before any final decisions are made. This is a requirement for any hospitals with greater than $\$ 100$ million in assets, acquiring a hospital with more than $\$ 10$ million in assets; and, the DOJ and the FCT make the final decision on these proposals to ensure there will not be any type of monopoly within a certain geographic areas. The Federal Trade Commission (FTC) and the Department of Justice (DOJ) are the two federal agencies that enforce antitrust violations. The Federal Trade Commission Act was established in 1914 and is charged with the oversight of commercial acts and practices; to maintain free and fair competition in the economy and to protect consumers from misleading practices. Both the DOJ and the FTC collaborate on antitrust law enforcement (Niles, 2018).

\section{PURPOSE OF THIS RESEARCH}

The department of justice and the Antitrust Division have a substantial role to play to ensure that American's consumers benefit fully from health care reform designed to maintain strong, competitive health care markets. Also, the Patient Protection and Affordable Care Act, signed into law and the Health Care and Education Reconciliation Act of 2010, signed into law on March 30 (collectively known as the Affordable Care Act) rely, in part on the principle that robust completion will expand coverage and increase consumer choices while containing cost. The House voted overwhelmingly, 406 to 19, to pass the Health Insurance Industry Fair Competition Act (H.R. 4626), to amend the McCarran-Ferguson Act to provide that nothing in the Act shall modify, impair, or supersede the operation of any of the antitrust laws with respect to the business of health insurance.

The role of antitrust is to ensure that competition is preserved and protected so that it can be harnessed. It is in the government interest to supports efforts that bring more competition to the health insurance marketplace that lowers costs, expand choice, improve quality; with the role of antitrust to ensure that competition is preserved and protected to help improving the U.S. health care system, together with regulation to expand coverage and control cost of health care for general population. Therefore, the purpose of this theoretical policy analysis report is to determine if antitrust laws should be based upon concrete wrongful conduct and should not force the health care industry to adopt defensive, cumbersome business practices that actually impede their ability to compete.

\section{RESEARCH PROBLEMS}

In the rule of law, the court did not determine whether closing the practice track of emergency medicine physicians was an antitrust violation and the court noted that the government or the health insurance industry, and not physicians would be the best enforcers of any certification action; health insurers, who compensate hospitals for most emergency care have a direct and economic interest in reducing the costs of emergency care. Therefore, the inability of uncertified emergency medicine physicians or competitors, to command the same competitive salaries as certified physicians did not constitute an antitrust violation because by requesting an injunction to temporarily restore the practice track, so that they could qualify for certification could be a major problem to the whole situation.

It is common to see antitrust litigation involving hospitals with respect to hospital-hospital relations, hospitalphysician relations and hospital-payer relations. It is evident that antitrust laws haves played critical role shaping modern medical markets which has resulted in antitrust laws helping usher the era of medicine as big business. Antitrust laws see hospitals as business firms organized to provide medical services and modern antitrust laws focus on a firm's behavior and not its objectives; hospital-firms are allowed to follow the function they like objectively as long as each of the objectives are pursued independently and avoid becoming a monopoly. Antitrust 
leaves it to the market to determine whether the achievements of a hospital-firm have social value (Hammer and Sage, 2003).

\section{SIGNIFICANT RESEARCH}

Whenever antitrust violations are claimed to have arisen, the government analyzes competitive balancing on a case-by-case basis and it often comes down to the government and the court weighing what constitutes competition in health care markets and then deciding how best to maximize social welfare or answering the questions of how high-quality, affordable health care can be made most accessible to the society. Therefore, it is significant to make sure that antitrust cases brought against health care providers should be tightly tied to defensible theories of wrongful conducts. The FTC enforces the antitrust laws to ensure that completion are allowed to stimulate the development of health care delivery systems as desired by consumers and as a result eliminated anticompetitive restraints to help market challenges that may create an environment in which innovative forms of health care delivery could emerge to compete on their merits (Steiger, 1995).

\section{ANALYSIS}

It is important to investigate special antitrust rules and exemptions for physicians H.R. 2425. The Medicare Preservation Act of 1995 was known to contain two antitrust provisions that the Commission and the Department of Justice opposed; section 15221 of H.R. 2425. According to the Assistant Attorney General of Antitrust Division at the U.S. department of Justice (1994), America with passage of the Sherman Act was the first nation to enact antitrust legislation that fostered competition through intelligent, vigorous and nonpartisan antitrust enforcement that did not diminish in the health care context because health care expenditures account for about one seventh of the Gross Domestic Product, and the health care industry employs over 9 million people.

According to Areeda and Hovenkamp (2015), antitrust laws balance potential pro-competitive benefits against potential anticompetitive effects. However, antitrust laws do not penalize health care providers that dominate their markets on their own merit, except those that intentionally dominate the market through wrongful conduct (Bork, 2009). If that is the case, antitrust cases brought against health care providers should require that defensive theories of wrongful conduct can be justified by laws (Brown, 2014). Brown, 2014; DOJ and FTC, 2010 suggested that:

- Any conduct by health care systems that is dominating a certain geographic market, such as hospitals paying nurses below-market wages and benefits wrongly should be banned

- The mergers and acquisitions of dominant health care systems that may threaten the competitive delivery of health care should be observed

- Anticompetitive practices that tend to lead to dominant positions in health care market should be prevented; and

- Any actions restricting competition, including unwinding the domination of multi-hospital health care systems in any region leading to abuse of market power must be prohibited

In analyzing competition, the antitrust laws need to focus more on unfair conduct that weaken or reduce competition, such as pricing agreements between competitors, and any mergers that may result in providers owning an unfair share of the market or exclusively restraining competition. A wrongful conduct of anticompetitive actions that are prohibited by antitrust laws, such as monopolization and conspiracies must also be strengthened. There must be evidence of specific intent to destroy competition in order to prove an attempt to monopolize; such intent is said to be determined by evaluating competitive tactics within the context of a health care provider's general business behavior. On the another hand, conspiracies in restraint of trade require different antitrust approaches as relationships among competitors in health care industry may evolve into conspiracies that threaten the competitive integrity of the marketplace in which such relationships are subject to close scrutiny (Areeda and Hovenkamp, 2015).

The researchers draw on recent antitrust cases in Idaho and Ohio when Federal Trade Commission successfully fought hospital merger plans. Case in point, Idaho's largest hospital network on June 12, 2012 asked the Ninth Circuit Court of Appeals to reverse a federal district judge's previous ruling of the purchase of Saltzer Medical Group by St. Luke's Health System, a nonprofit organizations that ends up owning about $80 \%$ of the doctor practices in the area. Saltzer Medical Group is known as the state's largest independent physician practice, while St. Luke's Health System is known as Idaho's largest hospital network. While St. Luke's argued that the district court erred in anticipating anti-competitive effects from the deal, the CEO of St. Luke's believes that that the appeal court's decision could have broader implications on whether antitrust laws can bar health systems in small to midsized markets from allowing the doctor groups to build new models of payment and delivery. The law suit pitted St. Luke's against its main competitor, St. Alphonsus Health System, Idaho's Attorney General and FTC. 
The court ruled that St. Luke's acquisition of the 40-doctor practice was a violation of antitrust laws that runs the risk of causing rising costs; and the state law prohibits acquisitions that would substantially lessen market competition (Packer-Tursman, 2014).

After nearly four years, the FTC began to fight the nonprofits merger, in another case in the same year, the U.S. Appeals Court upheld the FTC's administrative ruling that ProMedica Health System's 2010 acquisition of St. Luke's Hospital in Toledo also violated antitrust laws in Ohio. According to the case, in addition to ProMedica's three hospitals and St. Luke's, there are two other hospital systems in Toledo's Lucas County in Northwest Ohio; and the three-hospital system closed its deal with St. Luke's. Under the agreement with FTC, they failed to integrate certain parts of the business leading to FTC winning a preliminary injunction halting further integration and won administrative trial and appeal. ProMedica appealed to the Sixth Circuit and lost. In this case, FTC separated ProMedica's case out of obstetrical services by noting that the merged entities' OB services would comprise $81 \%$ of the market, and that their general acute-care services was $58 \%$. It is a believed that both FTC and the Justice Department provide a strong guidance for the healthcare industry on antitrust matters and as a result, courts are making it clear that they will traditionally apply basic principles about what a given healthcare transaction would do to prices and availability of care and quality of care (Packer-Tursman, 2014).

\section{DISCUSSIONS, CONCLUSIONS AND RECOMMENDATIONS}

After ProMedica asked the full Sixth Circuit appeals court for a rehearing, which is the next step before the Supreme Court can review the case again, the court's three-judge panel ruled against ProMedica; leading to ProMedica to ask for the full court of 12 justices to review the case again. In Idaho, the U.S. district Court ruled that St. Luke's Health System must immediately begin divesting its acquisition of the Saltzer Medical Group while it appeals the divestiture order. Also, the judge denied St. Luke's motion for a stay of the divestiture order pending appeal; asserting that St. Luke's is unlikely to succeed on appeal because the law and the facts clearly require divestiture of the merger as anti-competitive. And, according to Packer-Tursman, without a stay of the judge's order, St. Luke's must begin removing Saltzer from its operations, even if it succeeds in defending the merger's validity upon appeal (2014).

In the appeal filed, St. Luke's argues that the court applied the incorrect definition of "merger-specific" in its original ruling and imposed on the hospital and other defendants the burden of proving the absence of any less restrictive alternatives, rather than requiring plaintiffs, including St. Alphonsus Health System of Boise to prove the existence and effectiveness of those alternatives. According to Sullivan (2014), the FTC's intervention sends a mixed message as mergers and acquisitions between hospitals and doctors grow, and government regulators have generally encouraged such deals, as they tend to create cost efficiencies. ProMedica's dominance in the Toledoarea health market and charges that the health system uses its position to command much higher reimbursement rates from insurance companies in comparison with its competitors was known to be the crux of the ongoing anttrust case with the FTC. ProMedica officials dispute many of the assertions made by the FTC in various documents pertaining to the four-year court battle, but the U.S. 6th Circuit Court of Appeals in Cincinnati sided with the government agency last month and denied ProMedica's petition to overturn the FTC ruling issued in 2011 (HarrisTaylor, 2014). The judge went on to state that if St. Luke's is allowed to remain part of the ProMedica system, all ProMedica hospitals would be in an even more dominant position in the Toledo-area market and could unilaterally increase prices above competitive levels.

According to Harris-Taylor (2014), this is a four year legal battle between ProMedica and the federal agency, in which the federal agency is questioning whether pairing of ProMedica with St. Luke's will reduce the number of hospital systems in Lucas County from four to three and would ultimately result in higher prices for consumers. Before the merger, ProMedica controlled nearly 47\% of the market, compared to 28\% for Mercy, the secondlargest health provider in the area. The University of Toledo Medical Center, the former Medical College of Ohio, had $13 \%$ of the market, followed by St. Luke's, with just over $11 \%$. These are the figures quoted on the appeals court decision that sided with FTC. In conclusion, St. Luke's was struggling financially before the merger and the FTC officials during their investigation indicated that ProMedica was actually trying to inflict more financial hardship on St. Luke's and that ProMedica sought repeatedly to induce insurance companies to exclude St. Luke's from their networks.

It is concluded that the Federal Trade Commission views mergers and /or acquisitions that result in higher costs with a suspicious eye because the number of them has risen on in a recent years; and FTC are also concern about the relationship between brand-name pharmaceuticals and generic manufacturers regarding artificial methods of protecting patents and keeping generic drugs of the market. Therefore, antitrust cases and sanctions need to be tightly tied to defensible theories of wrongful conduct in order to properly reflect what society thinks is wrong and clarify what is punishable conduct. 


\section{REFERENCES}

Areeda, S. A. and Hovenkamp, H. (2015). Antitrust law: An analysis of antitrust principles and their applications. (4th ed.). New York, NY: Aspen Law and Business.

Bork, R. H. (2009). A time to speak: Selected writings and arguments. Wilmington, DE: Intercollegiate Studies Institute.

Brown, E. C. F. (2014). Irrational hospital pricing. Houston Journal of Health Law and Policy, 14, 11-58.

Centers for Medicare and Medicaid (CMS) (2015). National healthcare expenditure reports. Baltimore, MD: CMS.

Department of Justice \& Federal Trade Commission, Statements of Antitrust Enforcement Policy in Health Care, Statement 8. (1996). [hereinafter Health Care Policy Statements]. Available at: http://www.justice.gov/atr/public/guidelines/1791.pdf.

DOJ (U.S. Department of Justice \& FCT (Federal Trade Commission) (2010_. Horizontal merger guidelines. Washington, DC: DOJ-FTC.

Hammer, P. J. and Sage, W. M. (2003). Critical issues in hospital antitrust law. Health Affairs. Health Affairs, 22(6), 88-100. Available at: https://doi.org/10.1377/hlthaff.22.6.88

Harris-Taylor, M. (2014). ProMedica vs. the FTC: system's dominance is at heart of anti-trust case. Available at: http:/ /www.toledoblade.com/Medical/2014/05/18/ProMedica-vs-the-FTC.html

Health Insurance Industry Fair Competition Act, H.R. 4626, 111th Cong. (2010).

Niles, N. J. (2018). Basics of the U.S. health care system. Jones \& Bartlett Learning, Burlington, MA. Third Edition.

Steiger, J. D. (1995). Health care antitrust enforcement issues. The health trustee institute, Cleveland, Ohio. Federal Trade Commission: Protecting American's consumers. Available at: https://www.ftc.gov/publicstatements/1995/11/health-care-antitrust-enforcement-issues

Sullivan, K. (2014). St. Luke's appeals judge's ruling to unwind physician acquisition. FierceHealthcare. Available at: https://www.fiercehealthcare.com/healthcare/st-luke-s-appeals-judge-s-ruling-to-unwind-physicianacquisition

Packer-Tursman, J. (2014). Updated: two hospital antitrust cases you should be watching. Available at: https://www.healthcaredive.com/news/updated-two-hospital-antitrust-cases-you-should-bewatching/275818/

Patient Protection and Affordable Care Act, H.R. 3590, 111th Cong. (2010). 